\title{
Hydrocarbon geological aspects of subsidence curves: interpretations based on released wells in the Danish Central Graben
}

\author{
JENS MORTEN HANSEN and NAJA MIKKELSEN
}

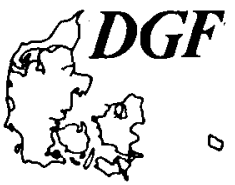

\begin{abstract}
Hansen, J. M. \& Mikkelsen, N.: Hydrocarbon geological aspects of subsidence curves: interpretations based on released wells in the Danish Central Graben. Bull. geol. Soc. Denmark, vol. 31, pp. 159-169. Copenhagen March 7th 1983.

The lithostratigraphy of the Danish Central Graben sequence is briefly outlined and the lithostratigraphic subdivision tabulated for 23 released wells. A simple subsidence model for the periode from Triassic to Recent is established exclusively with reference to the presented well data. The model points to pronounced changes in the rate of subsidence through Mesozoic and Cenozoic times with major changes taking place during late Jurassic and late Neogene. Based on the subsidence model it is suggested, that possible sourcerocks of Carboniferous or older ages were mature by late Cretaceous time. The presumably most promising sourcerock of the Central Graben, the upper Jurassic J-4 unit, reached the hydrocarbon generating level during early Tertiary in the deeper parts of the Graben whereas extensive hydrocarbon generation in the shallower parts did not reach a maximum before Neogene according to the present model.
\end{abstract}

Jens Morten Hansen and Naja Mikkelsen, Geological Survey of Denmark, 31 Thoravej, DK-2400 Copenhagen NV, Denmark, December 15th 1982.

\section{Introduction}

In the Danish off-shore area nearly 50 exploration wells have been drilled since 1966 when the search for hydrocarbons was initiated in the Danish North Sea sector. The area of primary interest is the Central Graben area where the majority of the off-shore wells have been drilled (fig. 1). The first off-shore wells were described in Rasmussen (1974, 1978), Michelsen (1975, 1976 a, b, 1978) and Bertelsen (1978, 1980). Detailed information on the lithology of released Central Graben wells together with a comprehensive description of the geological, sedimentary and structural history of the Central Graben was recently compiled by the staff of the Geological Survey of Denmark (Michelsen, 1982). The present report tabulates data presented in Michelsen (op. cit.) for 23 released wells (table 2 and 3 ). On the basis of these well data subsidence rates for the various formations are estimated and subsidence curves constructed for the graben area.

An important relation in oil exploration is the understanding of timing of oil generation, oil migration and trap formation in a given area. The generation is closely related to burial depth of a potential sourcerock, and the accumulation and trapping to the presence of suitable reservoir rocks and traps. The present paper presents a discussion of the assesment of the important timing of hydrocarbon generation and trap formation in the Danish Central Graben as inferred from the constructed subsidence curves. The paper is based on a number of assumptions and hypotheses concerning hydrocarbon generation. These premises are not discussed in detail, as a special group under the auspice of the Geological Survey of Denmark is presently working on these problems. The purpose of this paper is merely to present and discuss a possible model for the geological evolution of the Danish Central Graben as deduced form released well data. 


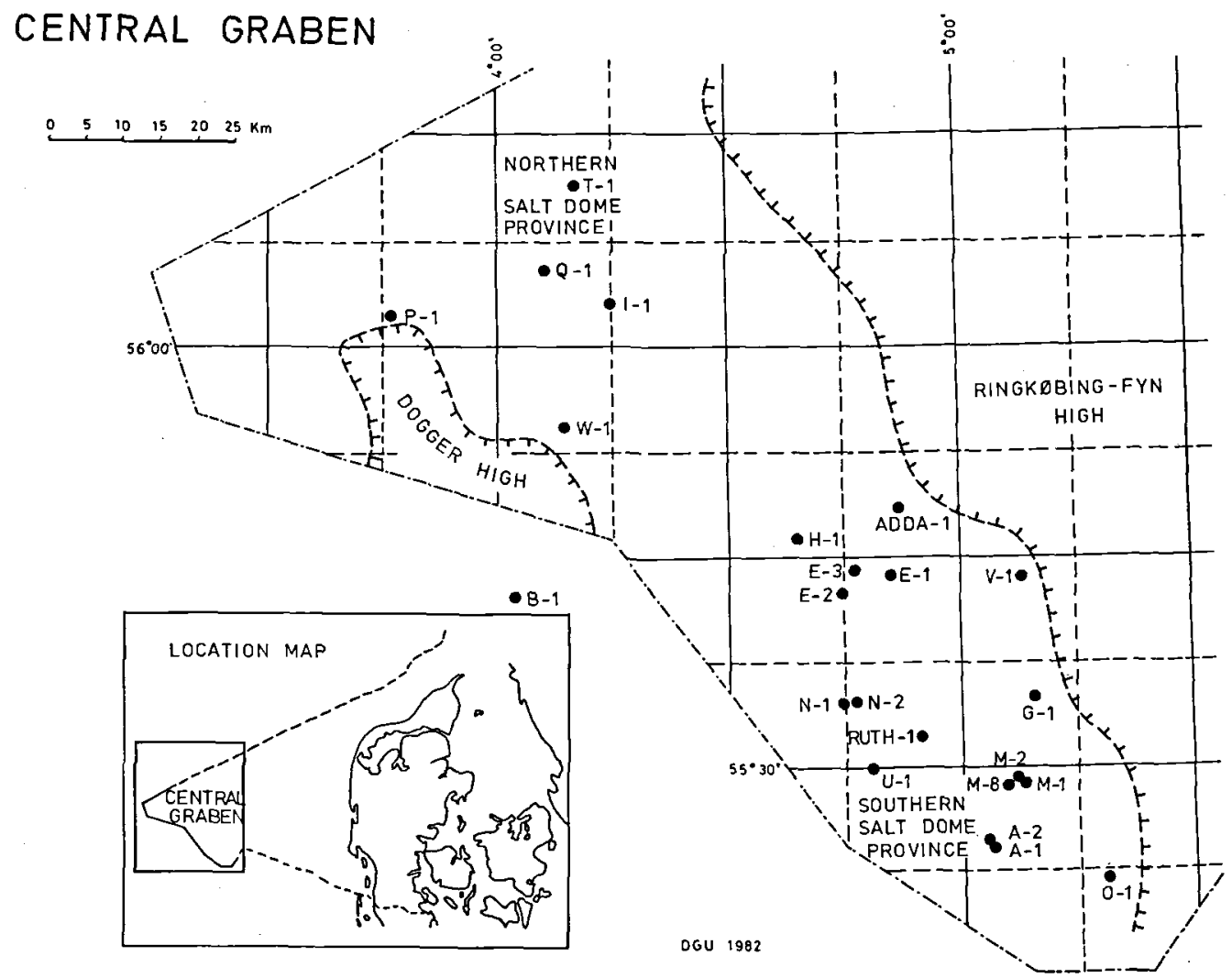

Fig. 1. Location of exploration wells in the Danish Central Graben with a simplyfied outline of major structural elements in the area (after Michelsen, 1982).

\section{Lithostratigraphy of the Danish Central Graben}

A lithostratigraphic subdivision of formations in the Central Graben area was recently established and described (cf. table 1 and Michelsen, 1982).

The Carboniferous is represented by interbedded shale and sandstone with minor coal seams. The Rotliegendes Group of the Permian consists mainly of claystone and marlstone with some sandstone and several volcanic sequences. The Zechstein Group is characterized by marine carbonate and by evaporite dominated by rock-salt and anhydrite, and the Triassic sequence by variegated claystone with alternating series of mainly anhydrite and halite.

The Jurassic sequence is dominated by brown to grey shale and claystone, which are fairly well indurated and especially in the J-4 unit with a good source rock potential. The Jurassic clay- stone sequences are interbedded with sand units in the middle part (the J-2 unit) and locally also in the topmost part (the W-1 unit). These sand units are of great interest as possible reservoirs in future exploration. The lithological units of the lower Cretaceous are mainly represented by greyish marl and mudstone, which along fault scarps may be interbedded with prominent sand sequences (the LC-1 unit).

The Upper Cretaceous is characterized by chalk and limestone, which are important oil reservoirs in the North Sea.

The Tertiary and Quaternary sediments cover the Central Graben area with a thick sequence of partly unconsolidated clay, silt and sand.

The complex tectonic evolution of the Central Graben area is reflected by the lithostratigraphy of the sections drilled in various parts of the trough (table 2 and 3 ). The sedimentary sequences and the unconformities recorded in the 
Table 1.

Lithostratigraphic subdivisions of formations in the Central Graben with designation of geological age and dominating lithology (after Michelsen. 1982).

\begin{tabular}{|c|c|c|c|}
\hline $\begin{array}{l}\text { Age } \\
\text { M.Y. }\end{array}$ & $\begin{array}{l}\text { Geological } \\
\text { period }\end{array}$ & $\begin{array}{l}\text { Lithological } \\
\text { Unit/Formation }\end{array}$ & Dominating Lithology \\
\hline \multirow{7}{*}{1,8} & Quaternary & CEN - 6 Unit & Silt, sand \& gravel \\
\hline & \multirow{6}{*}{ Tertiary } & CEN-5Unit & Clay \& sand \\
\hline & & CEN-4Unit & Clay \& Claystone \\
\hline & & CEN-3Unit & Claystone \\
\hline & & CEN-2 Unit & Claystone w. volcanic ash \\
\hline & & CEN-IUnit & Clay \& shale \\
\hline & & North Sea Marl & Marl and calcareous clay \\
\hline \multirow{9}{*}{65} & \multirow{6}{*}{$\begin{array}{r}\mathrm{L} \\
A \\
T \\
E \\
\text { Cretaceous }\end{array}$} & Chalk - 6 Unit & Chalk \\
\hline & & Chalk - 5 Unit & Chalk \\
\hline & & Chalk - 4 Unit & Chalk \\
\hline & & Chalk - 3 Unit & Chalk \\
\hline & & Chalk- 2 Unit & Chalk \\
\hline & & Chalk-1 Unit & Chalk \\
\hline & \multirow{3}{*}{$\begin{array}{l}E \\
A \\
R \\
L \\
Y\end{array}$} & Rodby $\mathrm{Fm}$ & Marl, mudstone \& shale \\
\hline & & Valhall Fm & Mudstone, shale \& marl \\
\hline & & $L C-1$ Unit & Sand - and siltstone \\
\hline \multirow{5}{*}{141} & \multirow{2}{*}{$L$} & $J-4$ Unit & Claystone \\
\hline & & $w-1$ Unit & Sandstone and siltstone \\
\hline & \multirow[t]{3}{*}{ Jurassic } & $J-3$ Unit & Claystone \& siltstone \\
\hline & & $J-2$ Unit & Claystone, sandstone $\&$ sand w. coal \\
\hline & & Fjerritslev Fm & Claystone \\
\hline \multirow{4}{*}{$195-$} & \multirow[b]{3}{*}{ Trincoin } & Winter ton $\mathrm{Fm}$ & Claystone \\
\hline & & Triton Anhydritic Fm & Claystone, marlstone \& anhydrite \\
\hline & & Dudgeon Saliferous & Claystone w. anhydrite and dolomite \\
\hline & ITIassic & Dowsing Dolomitic Fm & Clay-and marlstone w. anhydrite \& halite \\
\hline \multirow{4}{*}{$230-$} & $E]$ & Bachton Gr. & Claystone, shale $\&$ sandstone \\
\hline & \multirow{2}{*}{ Permian } & Zechstein Gr. & Evaporites (rocksalt, anhydrite, dolomite) \\
\hline & & Rotliegendes $\mathrm{Gr}$. & Claystone, sandstone \& volcanic sequences \\
\hline & Carboniferous & $C_{A}-1$ Unit & Shale $\&$ sandstone w. coal \\
\hline
\end{tabular}

wells thus witness the changing conditions in the fault controlled graben area. The subsidence was presumably initiated during the Permian and major rifting and fault movements continued during the Mesozoic. The area is characterized by a set of different structural elements (Michelsen, 1982) the most prominent of which are the southern and northern saltdome provinces, two areas highly affected by halokinesis, and the Dogger High area, a horst structure in the central part of the graben (fig. 1). The Ringkøbing-Fyn
High is - at least partly - a Pre-Cambrian basement high bordering the Central Graben to the east.

Hydrocarbon-geological aspects of the Central Graben

A long series of dynamic geological conditions must be fulfilled if hydrocarbons are to be generated, accumulated and preserved for exploitation. 
Table 2 and 3.

Lithostratigraphic subdivision of Danish Central Graben wells. Depths are given in meters below Mean Sea Level (after Michelsen, 1982). Legend for symbols used in tables:? boundary or thickness questionable, $\%$ formation or unit absent, $x$ interval not evaluated, 5327 total depth, $\times \times \times 253-789$ interval from 253 to 789 is not evaluated, i.e. the relevant formations may or may not be present.

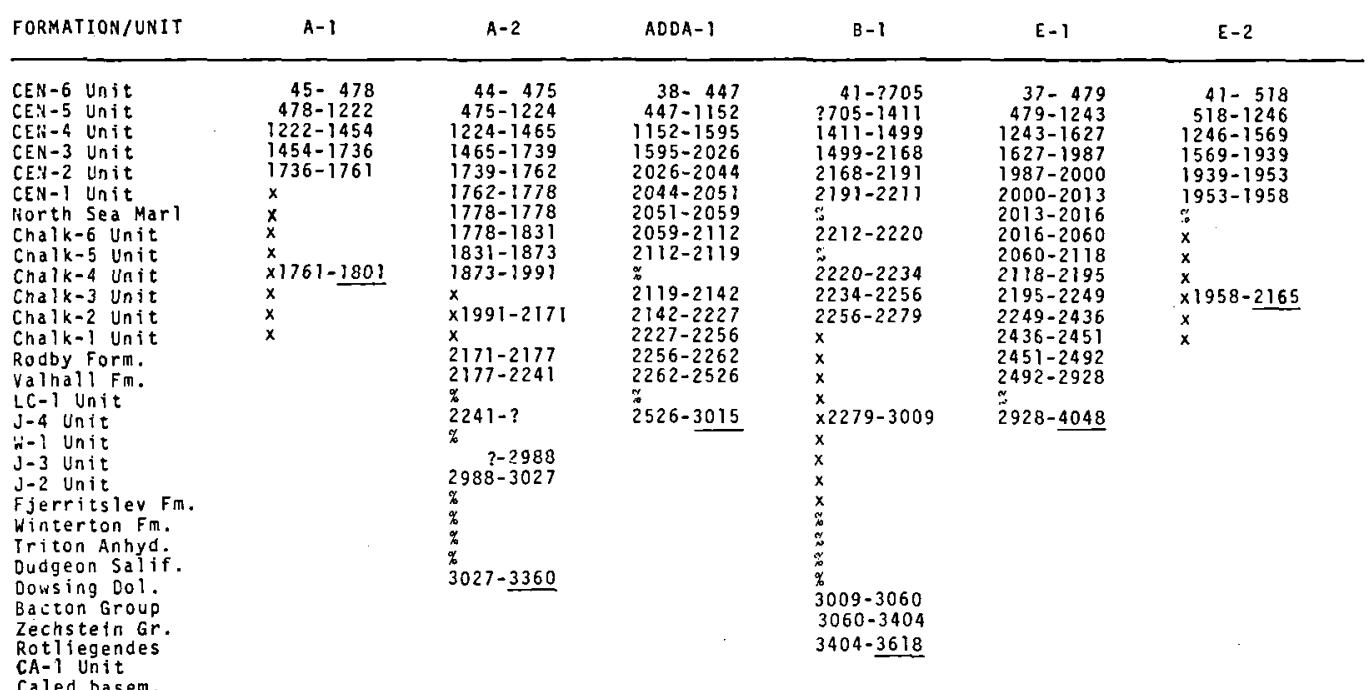

\begin{tabular}{|c|c|c|c|c|c|c|}
\hline FORMATION/UNIT & $E-3$ & G-1 & $H-I$ & $I-T$ & $M-1$ & $M-2$ \\
\hline $\begin{array}{l}\text { CEN-6 Unit } \\
\text { CEN-5 Unit } \\
\text { CEN-4 Unit } \\
\text { CEN-3 Unit } \\
\text { CEN-2 Unit } \\
\text { CEN-1 Unit } \\
\text { North Sea Marl } \\
\text { Chalk-6 Unit } \\
\text { Chalk-5 Unit } \\
\text { Chalk-4 Unit } \\
\text { Chalk-3 Unit } \\
\text { Chalk-2 Unit } \\
\text { Chalk-l Unit } \\
\text { Rodby Form. } \\
\text { Valhall Fm. } \\
\text { L-1 Unit } \\
\text { J-4 Unit } \\
\text { H-1 Unit } \\
\text { J-3 Unit } \\
\text { J-2 Unit } \\
\text { Fjerritslev Fm. } \\
\text { Winterton Fm. } \\
\text { Triton Anhyd. } \\
\text { Dudgeon Salif. } \\
\text { Dowsing Dol. } \\
\text { BactonGroup } \\
\text { ZeChstein Gr. } \\
\text { Rotliegendes } \\
\text { CA-l Unit } \\
\text { Caled. basem. }\end{array}$ & $\begin{array}{l}x \\
x \\
x \\
x \\
x \\
x \\
x 37-2502 \\
x \\
x \\
x \\
x \\
x \\
x \\
2502-2515 \\
2515-2528 \\
\end{array}$ & $\begin{array}{r}49-414 \\
414-1147 \\
1147-1587 \\
1587-1929 \\
1929-1948 \\
1948-1978 \\
\% \\
1978-2032 \\
2032-2045 \\
2045-2058 \\
2058-2133 \\
2133-2222 \\
\% \\
\% \\
2222-2429 \\
\% \\
2429-3632 \\
\% \\
3632-3778\end{array}$ & $\begin{array}{r}46-555 \\
555-1293 \\
1293-1565 \\
1565-1981 \\
1981-1996 \\
1996-1999 \\
\% \\
1999-2009 \\
2009-2091 \\
2091-2127\end{array}$ & $\begin{array}{r}57-542 \\
542-1465 \\
1465-1644 \\
1644-2669 \\
2669-2688 \\
2688-2709 \\
2709-2727 \\
2727-2761 \\
2761-2779 \\
2779-2814 \\
\% \\
\% \\
\% \\
\% \\
2815-2862 \\
2862-3321 \\
\% \\
3321-3879\end{array}$ & $\begin{array}{r}43-450 \\
450-1190 \\
1190-1460 \\
1460-1730 \\
1730-1744 \\
1744-1765 ? \\
\% \\
? 1765-1805 \\
1805-1831 \\
1831-1939 \\
1939-1975 \\
1975-2057 \\
x \\
2057-2071 \\
2071-2159 \\
\% \\
2159-2475\end{array}$ & $\begin{array}{r}41-466 \\
466-1209 \\
1209-1487 \\
1487-1793 \\
1793-1807 \\
\times \\
x \\
x \\
\times \\
\times 1807-2024 \\
x \\
x \\
x\end{array}$ \\
\hline
\end{tabular}

The most important of these conditions are the quality of possible source and reservoir rocks, the depositional environment, and burial depth of the formations. Secondly, the right timing of sourcerock maturation, trap generation, and hydrocarbon expulsion and migration is essential for the hydrocarbon accumulation. Finally, the "post-trapping" geological events such as deformation and diagenesis of reservoirs are important for the preservation of hydrocarbon accumulations and for their exploitability.

\section{Subsidence of the Central Graben}

The burial depth of a formation is a function of its age and geological setting. It may vary considerably within a limited area as a result of e.g. 


\begin{tabular}{|c|c|c|c|c|c|c|}
\hline FORMATION/UNIT & $M-8$ & $N=1$ & $\mathrm{~N}-2$ & $0-1$ & $P-1$ & $Q-1$ \\
\hline $\begin{array}{l}\text { CEN-6 Unit } \\
\text { CEN-5 Unit } \\
\text { CEN-4 Unit } \\
\text { CEN-3 Unit } \\
\text { CEN-2 Unit } \\
\text { CEN-1 Unit } \\
\text { North Sea Marl } \\
\text { Chalk-6 Unit } \\
\text { Chalk-5 Unit } \\
\text { Chalk-4 Unit } \\
\text { Chalk-3 Unit } \\
\text { Chalk-2 Unit } \\
\text { Chalk-1 Unjt } \\
\text { Rodby Form. } \\
\text { Valhal Fm. } \\
\text { LC-1 Unit } \\
\text { J-4 Unit } \\
\text { W-1 Unit } \\
\text { J-3 Unit } \\
\text { J-2 Unit } \\
\text { Fjerritslev Fm. } \\
\text { Winterton Fm. } \\
\text { Triton Anhyd. } \\
\text { Dudgeon Salif. } \\
\text { Dowsing Dol. } \\
\text { Bacton Group } \\
\text { ZeChstein Gr. } \\
\text { Rotliegendes } \\
\text { CA-l Unit } \\
\text { Caled. basem. }\end{array}$ & $\begin{array}{l}43-458 \\
458-1198 \\
1198-1476 \\
1476-1769 \\
1769-1784 \\
x 1784-1803 \\
x \\
1803-1846 \\
1846-1877 \\
1877-2007 \\
2007-2067 \\
2067-2169 \\
\% \\
2169-2190 \\
2190-2262 \\
\% \\
2262-2695 \\
\% \\
2695-3062 \\
3062-3167 \\
3161-3253 \\
3253-3260 \\
3260-3494 \\
3494-3647\end{array}$ & $\begin{array}{r}39-586 \\
586-1380 \\
1380-1638 \\
1638-2030 \\
2030-2040 \\
2040-2052 \\
2052-2070 \\
2070-2082 \\
2082-2746 \\
2146-2328 \\
2328-2377 \\
2377-2453 \\
\end{array}$ & $\begin{array}{l}37-607 \\
607-1362 \\
1362-1596 \\
1596-1948 \\
1948-1964 \\
1964-1977 \\
x \\
x \\
x \\
x 1977-2257 \\
x \\
x \\
x\end{array}$ & $\begin{array}{r}43-415 \\
415-1218 \\
1218-1479 \\
1479-1796 \\
1796-1811 \\
1811-1814 \\
1814-1830 \\
1830-1878 \\
1878-2163 \\
2163-2212 \\
2212-2230 \\
2230-2258 \\
2258-2280 \\
2280-2283 \\
2283-? \\
\% \\
x \\
\% \\
? \\
2685-2685 \\
2971-3126 \\
3126-3142 \\
3142-3384 \\
3384-3550 \\
\end{array}$ & $\begin{array}{l}66-600 \\
600-1454 \\
1454-1636 \\
1636-2766 \\
2766-2791 \\
2791-2859 \\
2859-2882 \\
2882-2955 \\
2955-2969 \\
2969-3117 \\
\% \\
\% \\
\% \\
\% \\
\% \\
\% \\
\% \\
\% \\
\% \\
\% \\
\% \\
\% \\
\% \\
\% \\
\% \\
\% \\
\% \\
3117-3327 \\
3327-3394 \\
3394-3458\end{array}$ & $\begin{array}{r}60-595 \\
595-1485 \\
1485-1834 \\
1834-2924 \\
2924-2946 \\
2946-3001 \\
3001-3028 \\
3028-3125 \\
3125-3233 \\
3233-3510 \\
3510-3659 \\
3659-3925 \\
x \\
x \\
x \\
\times 3925-4063 \\
x \\
x \\
x \\
4063-4111 \\
4111-4203 \\
6 \\
\% \\
\% \\
\% \\
4 \\
4203-4347 \\
4347-4386 \\
4386-4457\end{array}$ \\
\hline
\end{tabular}

\begin{tabular}{|c|c|c|c|c|c|}
\hline FURMATION/UNIT & Ruth-1 & $T=1$ & $U=1$ & $V-7$ & $W-1$ \\
\hline $\begin{array}{l}\text { CEN-6 Unit } \\
\text { CEN-5 Unit } \\
\text { CEN-4 Unit } \\
\text { CEN-3 Unit } \\
\text { CEN-2 Unit } \\
\text { CEN-1 Unit } \\
\text { North Sea Marl } \\
\text { Chalk-6 Unit } \\
\text { Chalk-5 Unit } \\
\text { Chalk-4 Unit } \\
\text { Chalk-3 Unit } \\
\text { Chalk-2 Unit } \\
\text { Chalk-1 Unit } \\
\text { Rodby Form. } \\
\text { Valhali Fm. } \\
\text { LC-1 Unit } \\
\text { J-4 Unit } \\
\text { W-1 Unit } \\
\text { J-3 Unit } \\
\text { J-2 Unit } \\
\text { Fjerritslev Fm. } \\
\text { Winterton Fm. } \\
\text { Triton Anhyd. } \\
\text { Dudgeon Salif. } \\
\text { Dowsing Dol. } \\
\text { Bacton Group } \\
\text { Zechstein Gr. } \\
\text { Rottiegendes } \\
\text { CA-i Unit } \\
\text { Cal }\end{array}$ & $\begin{array}{r}39-498 \\
498-1177 \\
1177-1385 \\
1385-1529 \\
1529-1546 \\
1546-1557 \\
\% \\
1551-1570 \\
1570-1577 \\
1577-1668 \\
\% \\
\% \\
\% \\
\% \\
\% \\
\% \\
\% \\
\% \\
\% \\
\% \\
\% \\
\% \\
\% \\
\% \\
\% \\
\% \\
\% \\
\% \\
\% \\
\% \\
\% \\
1668-1677\end{array}$ & 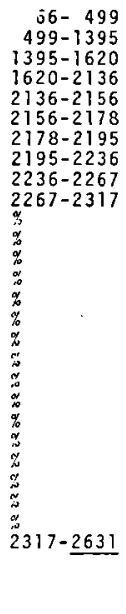 & $\begin{array}{r}43-604 \\
604-1456 \\
1456-1761 \\
1761-2165 \\
2165-2176 \\
2176-2190 \\
2190-2197 \\
2197-2238 \\
2238-2286 \\
2286-2349 \\
2349-2379 \\
2379-2445 \\
\% \\
\% \\
2445-2468 \\
\% \\
2468-2896 \\
\% \\
2896-3222 \\
3222-3340 \\
3340-3389 \\
3389-3401 \\
3401-3678 \\
3678-3957 \\
3957-4437 \\
4437-4962 \\
\end{array}$ & $\begin{array}{l}49-375 \\
375-1143 \\
1143-1659 \\
1659-2178 \\
2178-2192 \\
2192-2209 \\
\% \\
2208-2268 \\
2268-2295 \\
2295-2412 \\
2412-2519 \\
2519-2690 \\
\% \\
\% \\
2691-2702 \\
2702-2851 \\
2851-? 3198 \\
\% \\
? 3198-3648 \\
\% \\
\% \\
\% \\
\% \\
\% \\
\% \\
3 \\
3648-\underline{3}\end{array}$ & $\begin{array}{l}53-558 \\
558-1505 \\
1505-1673 \\
1673-2968 \\
2968-2997 \\
2997-3026 \\
3026-3055 ? \\
? 3055-3140 \\
3140-3226 \\
3226-3400 \\
3400-3557 \\
3557-3725 \\
\% \\
\% \\
\% \\
\% \\
\% \\
3725-4087 \\
4087-4184 \\
x \\
x \\
x \\
x \\
x 4184-4190 \\
x \\
x \\
x \\
4190-4199 \\
4199-4347\end{array}$ \\
\hline
\end{tabular}

halokinetic structures and deformational structures of regional significance. The accumulation rates are equivalent to the subsidence rates assuming, that the water depth has remained fairly uniform during deposition, and that the rate of post-depositional compaction has been equal in the various formations. It is evident, however, that none of these premises are completely fulfilled. The errors are nevertheless considered acceptable in the present context, since the possible variations in water depths during deposition and the magnitude of post-depositional differential compaction is rather small compared to the accumulation of sediment. This viewpoint is stressed by the fact that - disregarding the Chalk Group - more than $95 \%$ of the drilled Mesozoic and Cenozoic sequences included in this study are composed of fine-grained clastic sediments. According to available biostratigraphical reports from several companies these sediments were deposited in shelf environments, where the maximum changes in water depths during deposition did not exceed a few hundred meters. Furthermore, the relatively homogenous and 


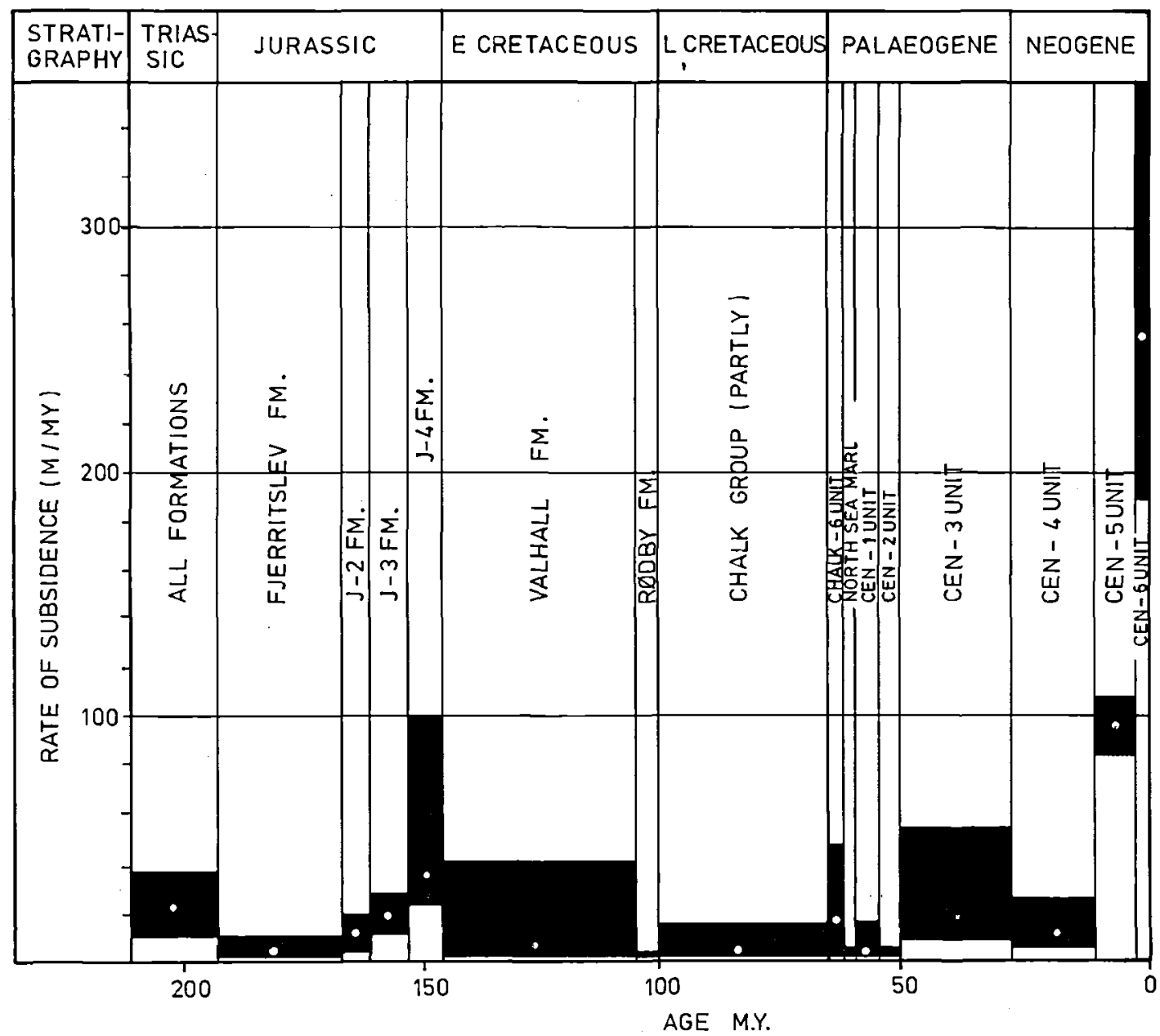

Fig. 2. Changes in rate of subsidence of the Central Graben area through time. The subsidence rates (maximum and minimum values) are based on well data. White dots indicate average values.

fine-grained nature of the overwhelmingly largest part of the total sedimentary sequence in the study area cannot have caused differential compaction in a scale comparable to the differential subsidence from period to period. Therefore, the errors inferred in the subsidence rates presented in fig. 2 are considered acceptable in the present general discussion, especially if the figures are corrected for errors inferred by the different nature of the Chalk Group compared to the bulk of the Mesozoic and Cenozoic formations.

The rate of subsidence has varied considerably through Mesozoic and Cenozoic times, and a number of phases of rapid subsidence as well as halokinetic phases appear to have had a strong impact on the actual burial depths. The late Jurassic and late Neogene phases af rapid subsidence are by far the most significant, as each of them increased the burial depth of older formations by up to $1500-2000 \mathrm{~m}$.

Until present most wells in the Danish North Sea sector have been drilled on halokinetic structures, which are responsible for the majority of the recorded minimum values of subsidence rates (fig. 2). From an overall point of view it may therefore be possible to trace periods of differential subsidence caused mainly by halokinesis. These periods should be characterized by differences in the maximum and minimum values of the rate of subsidence (fig. 2). Periods of com- 


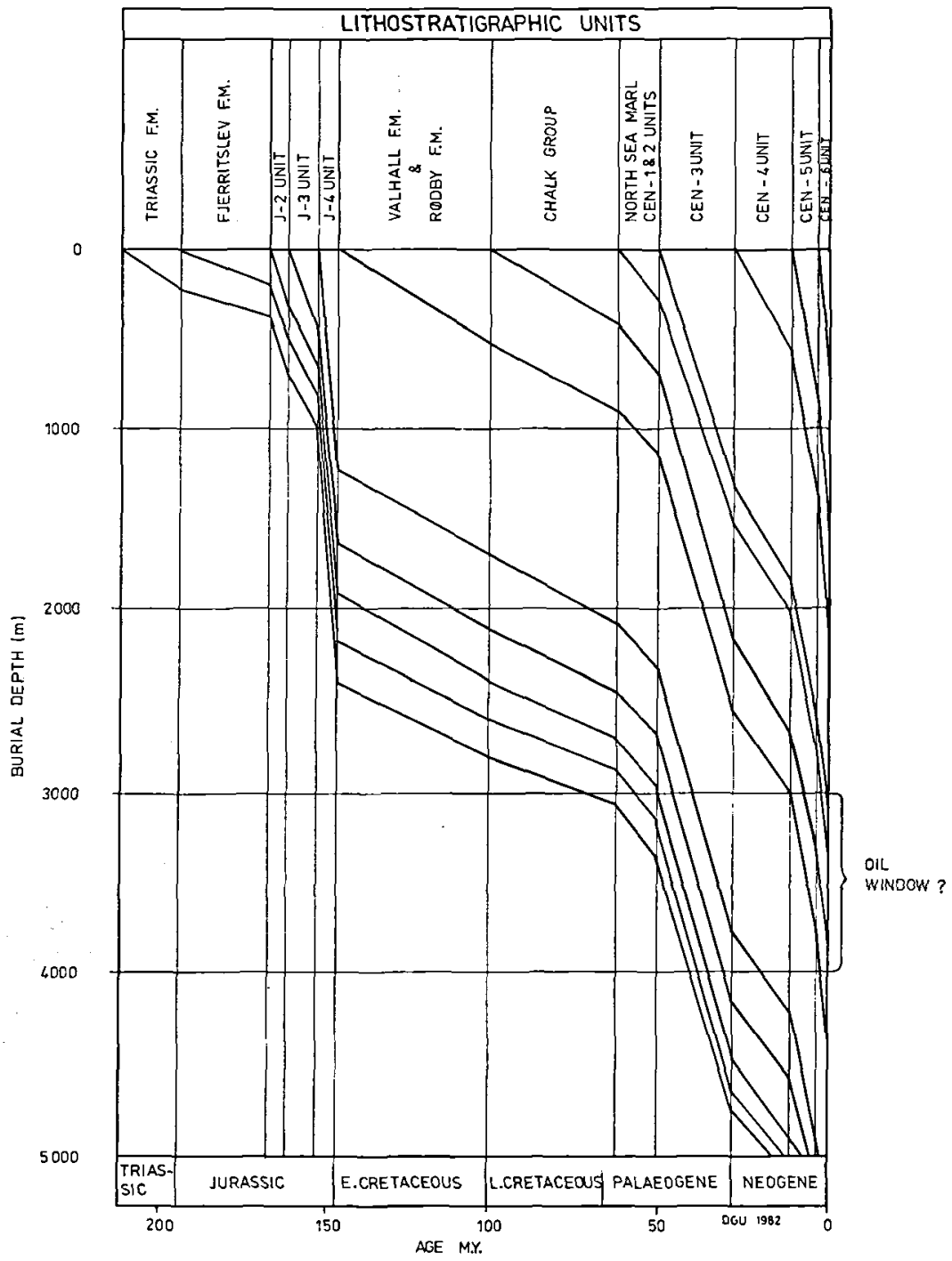

Fig. 3. "Maximum" subsidence curves for areas of the Central Graben least affected by tectonic instabilities. The curves are based on maximum formation thicknesses recorded in released well data. The burial depth at which oil generation is considered to take place is marked by "oil-window? $\propto$.

paratively marked differences in subsidence are the late Triassic, late Jurassic-early Cretaceous, Maastrichtian-Danian, late Palaeogene and Quaternary. Not only in the Central Graben but also in the Danish-Norwegian Basin these periods are characterized by relatively strong halokinesis (Michelsen et al., 1981; Hansen, 1981) and consequently also by differential subsidence.

The curves of subsidence rates (fig. 3 and 4) illustrate the burial depth of the various forma- tions at any given geological time. The "maximum" subsidence curves (fig. 3 ) are based on maximum formation thicknesses recorded in the wells. The "maximum" curves (fig. 3) thus represent subsiding locations least affected by tectonic (domal) structures in the graben, whereas the "average" curves (fig. 4) may represent parts of the graben area where instabilities as e.g. halokinesis to some extent have disturbed or reduced the general rate of subsidence. 


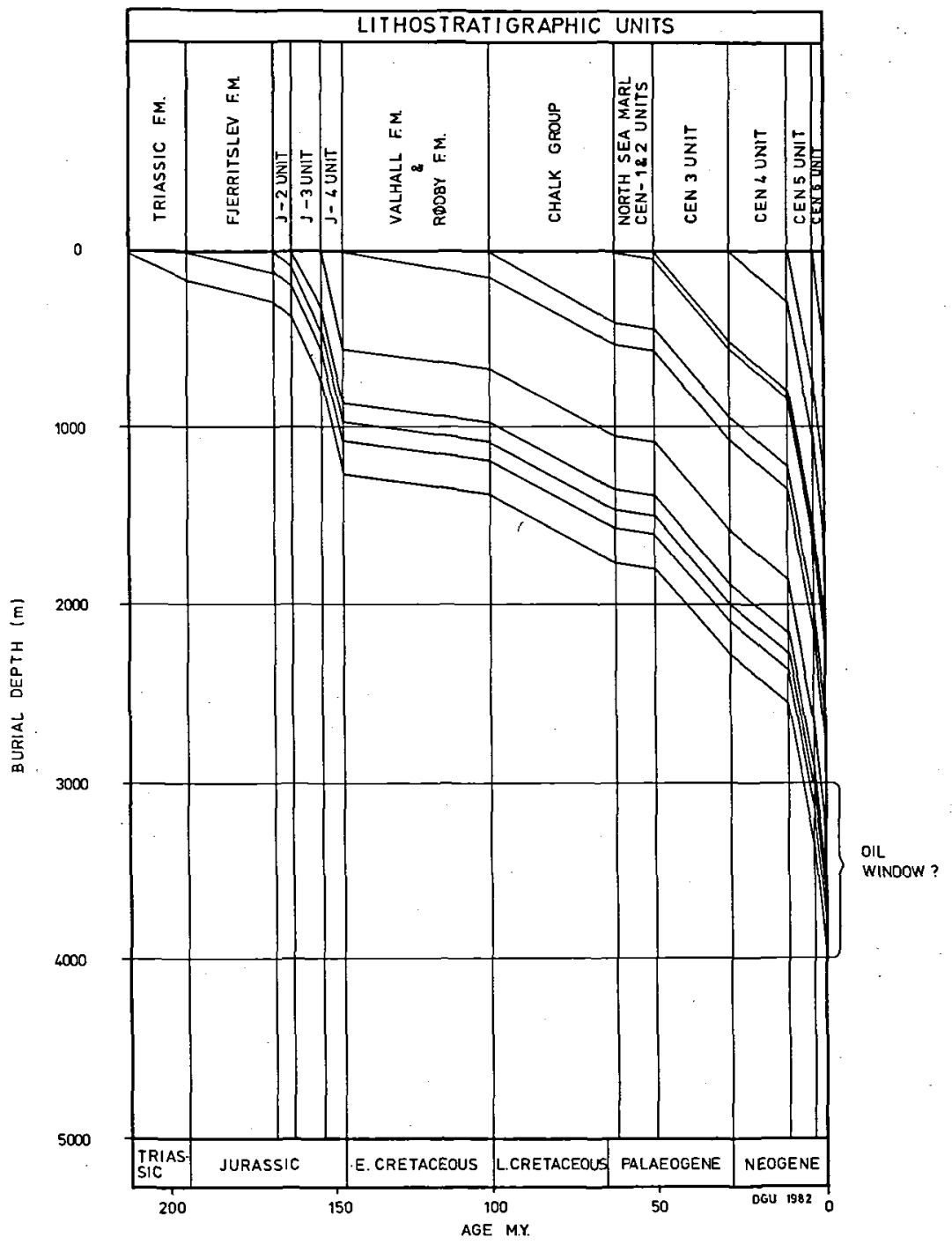

Fig. 4. "Average" subsidence curves for the Central Graben area based on average values of formation thicknesses recorded in released well data. The curves correspond to areas with partly reduced subsidence. The burial depth at which oil generation is considered to take places is marked by "oil-window?".

The subsidence curves may be applicable for a rough depiction of periods when potential sourcerock formations in Central Graben generated hydrocarbons, and when potential reservoir rocks were diagenetically altered and consequently, if the timing of the combined effect of the two factors from an explorationists point of view has been favourable or not for the accumulation of exploitable hydrocarbons.

\section{Erosion}

An important relation in the understanding of hydrocarbon generation, expulsion and migration is the understanding of the significance of erosion as a deloading process. Generally speaking erosion leads to or is a result of a relative uplift of previously more deeply buried formations, which consequently become "stored" under decreasing pressure and temperature. However, the magnitude of erosion cannot be directly depicted 
from drilled sequences. It has to be estimated by comparison of the magnitude of e.g. biostratigraphical hiati, by reflection seismic studies, or by breaks or sudden increases in the downhole maturation profile (e.g. sudden increase in vitrinite reflectance). Seismic and maturation studies of the Mesozoic sequences of the Danish Central Graben are in rapid progress, but do not at present allow any detailled understanding of the magnitude of erosion during the Mesozoic. On the other hand biostratigraphical studies (cf. Michelsen, 1982) have shown, that major hiati are present in the early-middle Jurassic, at the Jurassic-Cretaceous boundary, in the lower and lower upper Cretaceous and Paleocene sequences.

Among these, the early-middle Jurassic and upper Jurassic - lower Cretaceous hiati are related to shallow water depositions of sand sequences (J-2 unit and W-1 unit) (J.-O. Koch, pers. comm., 1982), which might indicate that erosion of some significance could have taken place during these periods. Most other hiati do not appear as related to significant deposition of coarse-grained clastic sediments in shallow water environments, indicating that these hiati might represent non-deposition more than erosion of thick sequences. It should therefore be expected that mainly middle and late Jurassic erosion could have lead to a reduced burial depths of older formation, and consequently that these older formation are in a slightly more mature state than directly deduceable from the subsidence curves presented in fig. 3 and 4.

\section{Hydrocarbon generation}

Generation and expulsion of hydrocarbons from a potential sourcerock depends among other factors on sourcerock richness and muturation. The latter is primarily related to time and temperature, and secondarily to the type of organic matter. Temperature as well as pressure may be expressed as a function of burial depth. An evaluation of the timing of hydrocarbon generation from potential sourcerocks is therefore possible under certain generalized assumptions. It is thus necessary to assume an almost constant geothermal gradient through time, which naturally may be a premise not fulfilled, since Ju- rassic rifting and volcanic phases may have caused higher geothermal gradients than that of the present. Moreover, the relatively high heatconductivity of rock-salt causes irregular temperature fields around halokinetic structures (Balling, 1979), and this will generally lead to positive temperature anomalies above salt domes and negative anomalies around the flanks. However, with reference to Jurassic sourcerocks, preliminary studies of Central Graben wells (Michelsen, 1982) seems to indicate that this "oil maturation-generation window" is roughly located at a burial depth between 3 and $4 \mathrm{~km}$ in the graben area.

Combining the assumptions on the depth of the "oil-window" with the subsidence curves a first hand evaluation is possible of the timing of hydrocarbon generation from potential source rocks. According to fig. 3, which is assumed to reflect the conditions in the more stable parts of the subsiding graben area, possible sourcerocks of Carboniferous or older ages were mature by late Cretaceous time. Unless elevated by tectonic movements immediately after the hydrocarbon generation - as might be the case on the bordering structural highs - they would today appear as "over-mature". The early Jurassic Fjerritslev Formation reached the "oil-window" during the Palaeogene whereas the presumably most promising sourcerock of the Central Graben, the late Jurassic J-4 unit, reached the hydrocarbon generating level during late Palaeogene and Neogene according to the present interpretations.

\section{Reservoir alteration}

A good reservoir is characterized by high porosity and permeability. Generally speaking, both parameters normally deteriorate during subsidence and burial due to mechanical compaction and chemical alterations (diagenesis). It should be stressed that $\log$, core, and test data from released wells in the Danish Central Graben at the present are so sparse, that the depth/porosity/permeability relations of coarse clastic sediments are speculative.

The middle Jurassic J-2 unit has only been drilled on structural highs in Central Graben, where it together with local upper Jurassic and lower Cretaceous sand beds presently is regarded 
as the most prospective reservoir below the Chalk Group. The J-2 unit is generally buried to a depth of more than $4000 \mathrm{~m}$ away from structural highs, and the formation porosity may consequently be considerably reduced in these areas. With the present knowledge, the J-2 unit may therefore be considered as a low porosity reservoir away from structural highs. However, on or close to structural highs, the J-2 unit may have remained buried to rather shallow depths until the late Cretaceous or Tertiary. In such cases better reservoir characteristics are likely to be found, and with the presence of appropriate seals this unit as well as upper Jurassic and lower Cretaceous sandstones may attract considerable attention as possible reservoirs in the future.

\section{Timing of hydrocarbon generation and reservoir formation}

Possible source and reservoir rocks of late Palaeozoic age may generally be too deeply seated in the graben to have any hydrocarbon potential, unless hydrocarbons have been expulsed and preserved for a considerable period of time at a shallower depth. On structural highs, however, the rifting phases could conceivably have elevated possible Palaeozoic source and reservoir rocks and created fault controlled contacts to younger formations.

As previously discussed, hydrocarbon generation from potential Jurassic sourcerocks like the Fjerritslev Formation and the J-4 unit hardly took place before the Tertiary. In the deeper parts of the graben hydrocarbon generation was thus initiated in the early Palaeogene and reached a maximum in the early Neogene according to the present interpretations (fig. 3), whilst hydrocarbon generation in the shallower parts of the graben hardly started before the Neogene and presumably did not reach a maximum before the Pliocene-Pleistocene (fig. 4). Moreover, it is well known that structural traps, e.g. saltdomes, faults and gentle arches, were formed at earlier dates. Thus, saltdomes may have evolved already during the late Triassic, Jurassic and Cretaceous time with a continued growth during Tertiary and possibly also Quaternary times. Deformational structures of regional significance are mainly related to the Cimmerian and Laramide tectonic events (Michelsen, 1982). Therefore, assuming that the upper Jurassic J-4 unit is one of the main sourcerock in Central Graben and that hydrocarbon mainly expulsed from it during Neogene time, one very important premise of the timing aspect appears fulfilled: Reservoirs as well as traps were formed before hydrocarbon was expulsed from the sourcerocks. Furthermore, the interpreted timing of the deposition of reservoir and seal sequences as well as the structural deformation (trap generation), sourcerock maturation, hydrocarbon expulsion and migration would indicate, that the hydrocarbon accumulation took place so late in the geological history, that the hydrocarbon reservoirs most likely have remained unaffected by regional tectonic events, whereas halokinetic movements may have induced some post-trapping effects to reservoirs related to salt structures.

Acknowledgements. The well data is based on the published co-operative work of our colleagues at the Geological Survey of Denmark.

\section{Dansk sammendrag}

Siden 1966 er der boret ca. 50 efterforskningsboringer i den danske del af Central Graven. Af disse er 23 boringer frigivet til offentliggørelse. På basis af disse boringers stratigrafiske inddeling, som er udarbejdet på Danmarks Geologiske Undersøgelse, og som er publiceret af Michelsen (1982), er der opstillet en model for Central Gravens indsynkningshistorie i Mesozoikum og Kænozoikum.

Denne model indikerer, at navnlig to indsynkningsfaser har bidraget til de begravelsesdybder som Central Gravens potentielle kilde- og reservoirbjergarter for olie og gas befinder sig p̊̊ idag. Der er således tale om en kraftig indsynkning $i$ øvre Jura og i Neogen. I hver af disse indsynkningsfaser er begravelsesdybden af ældre aflejringer forøget med op til 1500-2000 meter.

Under forudsætning af, at en række endnu kun delvis verificerede pramisser holder stik, søges de oliegeologiske aspekter af indsynkningsmodellen uddraget. Som væsentlige præmisser indgår en række generelle opfattelser, der for nærværende er under nærmere undersøgelse. Blandt disse generelle opfattelser skal især nævnes antagelsen om, at kulbrintedannelsen i de potentielle kildebjergarter hovedsagelig finder sted ved temperaturer og formationsaldre, som idag hovedsagelig forekommer på 3-4 kilometers dybde i den danske del af Central Graven. Det er derfor afgørende for områdets kulbrintepotentiale, hvornår potentielle kildebjergarter har passeret eller er kommet ind i dette "olievindue", idet en afgørende faktor for dannelsen af kommercielle kulbrinteansamlinger er rækkefalgen af kulbrintedannelsen, kulbrintemigrationen, aflejringen af mulige reservoirbjergarter og strukturdannelsen.

Det er artiklens konklusion, at uanset om de opstillede præmisser $\mathrm{i}$ mindre målestok skulle vise sig at være ukorrekte, er en vasentlig forudsætning for at gøre kommercielle oliefund til stede $\mathrm{i}$ den overvejende del af området. Dette begrundes med, at de potentielle øvre jurassiske kildebjergarter først er 
kommet ind i "olievinduet", efter at de potentielle reservoirbjergarter er aflejret og efter strukturdannelsen har fundet sted. Dette er formentlig forklaringen på de mange oliefund i de øvre kretaciske kalkstenslag. Med hensyn til muligheden for at gøre oliefund $i$ jurassiske og nedre kretaciske reservoirbjergarter diskuteres dette ud fra de ovenfor skitserede opfattelser. På grund af det meget lille antal boringer, som har gennemboret mulige jurassiske og nedre krataciske reservoirbjergarter, er det endnu ikke muligt at udtale sig kvalificeret herom.

Artiklen konkluderer at man $i$ forbindelse med de kommende udbudsrunder på forhånd må stille størst forventning til muligheden for at gøre kommercielle kulbrintefund $i$ de øvre jurassiske og nedre kretaciske sandsten, som hovedsagelig må formodes at forekomme i forbindelse med større forkastninger i eller langs kanterne af Central Graven. M.h.t. mulighederne for at gøre kommercielle kulbrintefund i triassiske og ældre formationer indikerer artiklen, at sådanne muligheder navnlig må formodes at være tilstede $\mathrm{i}$ hævningsområderne eller $\mathrm{i}$ områder, hvor ældre formationer er bragt i sideværts kontakt med potentielle jurassiske kildebjergarter for kulbrinter.

\section{References}

Balling, N. 1979: Subsurface temperatures and heat flow estimates in Denmark. In: Cermák \& Rybach (eds.), Terrestrial heatflow in Europe. Springer Verlag, Berlin, 161-171.

Bertelsen, F. 1978: The Upper Triassic-Lower Jurassic Vinding and Gassum Formations of the Norwegian-Danish basin. Danm. geol. Unders., Ser. B, 3, 1-26.
Bertelsen, F. 1980: Lithostratigraphy and depositional history of the Danish Triassic. Danm. geol. Unders., Ser. B, 4, $1-59$.

Hansen, J. M. 1981: Structural setting and halokinesis of the area of investigation In: Danm. geol. Unders.: $H y$ drogeological programme, Mors salt dome: Geological main report, Internal report. 229-256.

Michelsen, O. 1975: Lower Jurassic biostratigraphy and ostracods of the Danish Embayment. Danm. geol. Unders., II. rakke, 104, 1-287.

Michelsen, O. 1976 a: Preliminary report on the Jurassic lithostratigraphic nomenclature in the Danish North Sea area. Danm. geol. Unders., Årbog 1975, 105-116.

Michelsen, O. 1976 b: Kortfattet oversigt over de geologiske forhold i den danske del af Nordseen. Danm. geol. Unders., Ârbog 1975, 117-132.

Michelsen, O. 1978: Stratigraphy and distribution of Jurassic deposits of the Norwegian - Danish basin. Danm. geol. Unders., Ser. B, 2, 1-28.

Michelsen, O. et al. 1981: Kortlægning af potentielle geotermiske reservoirer i Danmark. Danm. geol. Unders., Ser. B, 5, 1-96.

Michelsen, O. (ed.) 1982: Geology of the Danish Central Graben. Danm. geol. Unders., Ser. B, 7, 1-135.

Rasmussen, L. B. 1974: Some geological results from the first Danish exploration wells in the North Sea. Danm. geol. Unders. III rakke, $42,1-46$.

Rasmussen, L. B. 1978: Geological aspects of the Danish North Sea sector. Danm. geol. Unders. III række, 44, 1-85. 